\title{
Spatial changes in the command and control function of cities based on the corporate centre of gravity model
}

\begin{abstract}
The aim of this paper is to discuss changes in the spatial distribution of cities that perform the command and control function created by the largest corporations, based on the method of gravity centres. The analysis was performed both for individual sectors of the economy as well as for the global scale. A shift occurred in an easterly direction. This also pertains to sector indices, although the centroids of knowledge-based sectors, such as information technology and healthcare, shifted the most in the direction of Asia. At the same time, information technology was the only sector whose centroid shifted to the west in the study period. Moreover, the magnitude of the shift of the centre of gravity of the number of corporate headquarters in the studied cities does not converge to the shift of the centroid based on the value of the financial potential of the companies.
\end{abstract}

\section{Keywords}

Command and control function $\cdot$ corporate financials $\cdot$ gravity model $•$ headquarters

(c) University of Warsaw - Faculty of Geography and Regional Studies
Piotr Raźniak $\mathbb{C}$, Sławomir Dorocki@, Anna Winiarczyk-Raźniak

Institute of Geography, Pedagogical University of Krakow Krakow, Poland

e-mail: piotr.razniak@up.krakow.p

e-mail: slawomir.dorocki@up.krakow.pl;

e-mail: anna.winiarczyk-razniak@up.krakow.pl

Received: 1 July 2019

Accepted: 14 November 2019
Introduction

Studies on intercity linkages between companies appear to be particularly interesting. This is true of both the ownership structure and linkages between companies. In the modern global economy, research on the command and control function of cities is important in relation to their geographic distribution (Śleszyński 2018).

In today's globalised world, the significance of geographic distance diminishes when considered in terms of the transfer of workforce and financial assets. Therefore, a trend is emerging that leads to the creation of an "international" economic system, while connectivity increases between corporations as well as between cities in general (Sassen 2000). The functions of large corporations have been studied multi-dimensionally over the last several decades. It was stated, in one of the seven hypotheses regarding the concept of the world city, that the global control functions of international corporations in world cities are directly related to the activity of the production sector (Friedmann 1986). This view is now outdated. Currently it is believed that firms in the advanced producer services sector (APS) are the main drivers of globalisation processes. These firms yield groups of cities (world cities) that serve as strategic places for economic globalisation processes (Taylor et al. 2014), although they are not the only strategic places in global connectivity networks (Goerzen et al. 2013).

The world city concept was developed by J.V. Beaverstock, R.G. Smith and P.J. Taylor (1999). The financial results of the largest corporations that generate the C\&C function of cities have also been the subject of analysis in the last 10 to 20 years. Studies of this type were conducted either on a global scale (Godfrey \& Zhou
1999, Alderson \& Beckfield 2004, Taylor \& Csomós 2012), on a continental scale (Csomós \& Derudder 2014, Dorocki, Raźniak \& Winiarczyk-Raźniak 2018), or on a regional scale (Raźniak, Dorocki \& Winiarczyk-Raźniak 2018). Diversification of the economy is an important element of the stabilisation and strengthening of regions (Masik 2016, 2019) and cities (Raźniak, Dorocki \& Winiarczyk-Raźniak 2019), which is an important element in the event of an economic crisis. The concept of the command and control function takes into account the presence of the largest corporations and their financial results. What is not considered, however, is the potential collapse of the dominant sector that helps create the command and control function of a city. Such a scenario was introduced by P. Raźniak, S. Dorocki \& A. Winiarczyk-Raźniak (2017), where the economic resistance of the command and control function of cities to a potential collapse of the dominant sector was also taken into account.

The subject of the economic centre of gravity of the world is currently discussed in the era of progressing globalisation. The problem of how to determine the location of the world's economic centre of gravity, or of a specific region and its change over time, as well as problems associated with relationships between geographic distance, economic potential and various measures of concentration in analyses of socio-economic phenomena, are all issues that have been discussed by many researchers including R.R. Boyce, W. A. V Clark (1964), B. Kostrubiec (1972), A. Scharlig (1973), L. Wojciechowski (2004), Ch. I-Hui \& H. J. Wall (2005), I. Jażdżewska (2006), L. R. Klein, (2009), D.Huanfeng, and L. Peiyi, (2009), J.-M. Grether, N.A Mathys (2010), D. Quah, (2011), Y Zhang I in. (2012), Á. Kincses, Z. Nagy, G. Tóth (2013), Ramos, Suriñach (2017), G. Csomós, G. Tóth (2016), S , Dorocki P. Raźniak (2017), S. Dorocki, P. Raźniak \& Winiarczyk-Raźniak (2019). 
The centre of gravity in the abovementioned works is defined as the spatial equivalent of the arithmetic mean. In order to identify the socio-economic centre of gravity, variables such as the size of GDP, population of cities, number of employees, and other measures describing socio-economic potential were used. Data on the number and distribution of the headquarters of the largest corporations as well as on their financial potential were used in this study. These indicators describe the rank and significance of cities in the modern, globalised world.

According to G. Csomós (2013), the command and control function is performed by 2,000 companies named on the Forbes Global 2000 list (Forbes Global 2000, 2018). Research studies exist, where the method of the centre of gravity of cities is applied, whether in the aspect of advanced R\&D activity (Tóth \& Csomós 2016) or a more general focus on their command and control functions (Csomós \& Tóth 2016).

There exists, however, no specific research on the financial results of corporations on the global scale, and especially on C\&C functions by sector. Given the above, the aim of this paper is to describe the centre of gravity and changes to it for the command and control function of cities in the years 2006 and 2016, both for individual economic sectors, as well as globally.

\section{From world cities to world economic centres}

The idea of the command and control function of a city, created by the financial power of large corporations, emerges in many studies and concepts describing the power of cities and their mutual relationships. One of the most important works in this area is the work by P. Hall (1966), who described the theoretical fundamentals of the concept of the world city. According to $P$. Hall, world cities are political centres, concentrating government institutions, trade unions and federations.

Studies on the global city theory increased in number throughout the 1980s (Friedmann \& Wolff 1982, Friedmann 1986, Sassen 1988). At present, the considerable mobility of capital seems to be the most important aspect of globalisation. Moreover, the significance of distance diminishes in terms of flow of labour and financial means. Therefore, there exists a trend to create a global economic system and to increase both the connectivity between cities as well as their influence (Sassen 1991, 2000). International corporations have noted a decisive increase in their significance since the 1970s, although the locations of their headquarters have often changed over the same period of time (Csomós \& Derudder 2014)

Analysis of the locations of corporate headquarters of the largest companies shows the specific strength of a city focusing on its command and control functions. In their research, P. J. Taylor and G. Csomós (2012) found that command and control functions are created by the largest world corporations on the Forbes Global 2000 list.

Based on the above-mentioned concepts, new indicators were also created showing the position of particular cities in a world-wide hierarchy of cities. At the end of the 1990s, J.V. Beaverstock, P.J. Taylor and R.G. Smith (1999) created an indicator, which showed the level of international connectivity between cities. In their research, they considered the location of corporate headquarters, regional, and local divisions of the largest 100 corporations from the advanced producer services sector, which comprised the following: accountancy, advertising, management consultancy, financial services and law. Beginning in the year 2000, the analysis was broadened and, in addition to the 100 corporations studied earlier, an additional 75 largest corporations on the Forbes Global 2000 list were also studied. Research efforts on intercity connectivity are currently being undertaken by many researchers looking for innovative concepts related to the subject (Liu et al. 2014, Liu, Derudder \&Taylor
2014, Hennemann \& Derudder 2014, Neal 2016, Yang et al. 2017, Neal, Derudder \& Taylor 2019).

The concepts of the command and control centre, global city, and world city (GaWC) illustrate the power of the city using various indicators. They do not deal with the possibility of a potential recession ("crisis") of a dominant sector, which possesses the ability to establish the command and control function of a city. Such a novel modification of the older concepts was presented by P. Raźniak, S. Dorocki \& A. Winiarczyk-Raźniak (2017). An "economic crisis" is understood by these three researchers as a decline in the financial results of firms in a given sector, because of which firms that belong to the sector are dropped from the Forbes Global 2000 list, which, in turn, causes the sector (both the sector and the firms that belong to it) to lose its ability to generate the command and control function for a given city.

\section{Data and methods}

The timeframe of the study is the years 2006 and 2016 . The former was the last year before the global financial crisis that began in the United States in 2007. The study illustrates the command and control function before the crisis in comparison to the latest data available to the authors for the year 2016.

The analysis in the study was performed using the list of the largest 2,000 corporations in the world, published by Forbes magazine (Forbes Global 2000, 2018). The centre of gravity was calculated based on the Corporation Potential Index (CPI) [2]. This indicator was produced based on data illustrating the potential of a city with respect to the standardised value of individual firms by the sector of their economic activity. The paper provides an analysis of revenue, income, market value, and asset values of the largest corporations in the years 2006 and 2016. The Sectoral Corporation Potential Index (SCPI) [1] was developed based on this data. The index was calculated based on average values standardised by the average value of the variable $(\bar{x})$ and its standard deviation (SD). The following four values - revenue, income, market value, and asset value for individual sectors - were assumed to be variables.

Any analysis of the command and control potential of cities also needs to consider the concentration of capital, as measured via the number of corporate headquarters. This is why the standardised financial results of companies were multiplied by the number of corporate headquarters located in a given city and divided by four. The value "four" is the value of the third quartile ( $75 \%$ of observations) of the number of corporate headquarters increased by 1 . Hence, if the number of headquarters in a given city was larger than 4 , then financial results were multiplied by a value larger than 1 . If the number of headquarters was smaller than 4, then the multiplier would assume values of less than one, thus reducing the financial benefit to the given city.

The number of headquarters (HQ) in a given city was assigned such high importance because the authors of this study believe that the international importance of a city is largely determined not only by the economic potential of individual corporate headquarters, but most of all by their actual number, which signifies the global influence of a given city. Therefore, it has been judged - based on analysis of data and earlier works - that at least 4 headquarters located in one city determines its global potential and significance for a given sector of the economy. However, in order to show the whole picture, as to where the headquarters of international corporations are located, all the cities included in the Forbes' ranking were considered. In order to exclude negative values of the index, the obtained average value was increased by the absolute value of the smallest value in the obtained sequence; in this manner, the index for the minimum value of the SCPI would equal zero. In order to calculate the global potential of a given city, expressed by Corporation Potential 


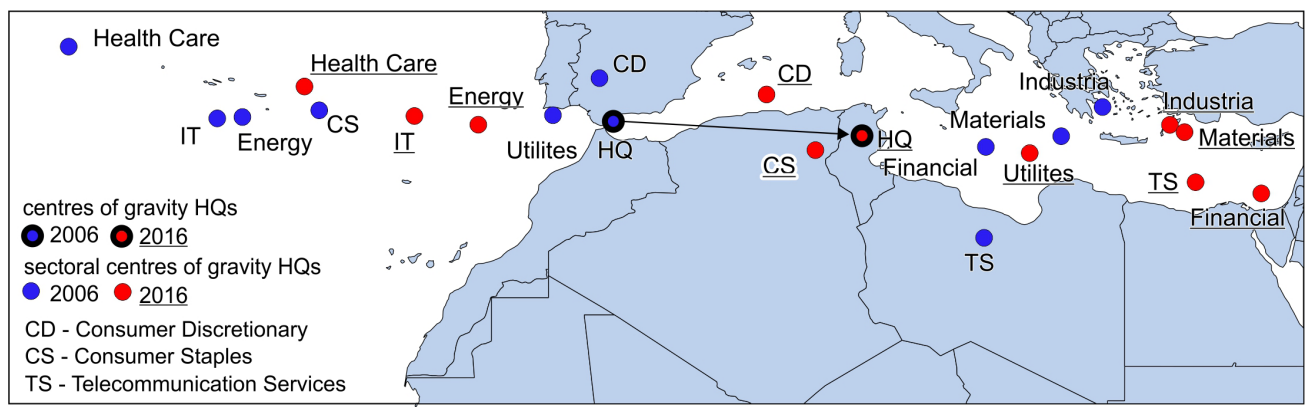

Figure 1. Centres of gravity based on the number of corporate headquarters in 2006 and 2016. Source: Authors' own work based on Forbes Global 2000 (Forbes Global 2000, 2018)

Index (CPI), a total was computed by adding the values of SCPI that were calculated earlier for individual sectors [2].

$$
\mathrm{SCPI}=\left(\frac{\sum_{\mathrm{i}=1}^{\mathrm{N}} \frac{\mathrm{x}_{\mathrm{i}}-\overline{\mathrm{x}}}{\mathrm{SD} D_{\mathrm{x}}}}{\mathrm{N}} \times \frac{\mathrm{HQ}}{4}\right)+\left|\left(\frac{\sum_{\mathrm{i}=1}^{\mathrm{N}} \frac{\mathrm{x}_{\mathrm{i}}-\overline{\mathrm{x}}}{\mathrm{SD} D_{\mathrm{x}}}}{\mathrm{N}} \times \frac{\mathrm{HQ}}{4}\right)_{\text {min }}\right|
$$

$\mathrm{CPI}=\sum_{\mathrm{i}=1}^{\mathrm{N}} \mathrm{SCPI}_{\mathrm{i}}$

where:

$x$-- value of variables for particular cities $(i)$ - that is, in this case, of four variables: revenue, profit, asset value, and market value for individual sectors of the economy

$\bar{x}$ - average value of variables for all cities by economic sector $\mathrm{SD}_{\mathrm{x}}$ - standard deviation of variables for all cities by economic sector

$\mathrm{N}$ - number of cities

$\mathrm{HQ}$ - number of headquarters of corporations in a given city by economic sector

$(\ldots)_{\min }-$ minimum value of the index for a given sector of the economy

Furthermore, based on the number of headquarters of corporations in the studied cities and the value of the $\mathrm{CPI}$ and the SCPI, the centre of gravity was calculated based on the coordinates of the centroid calculated using Formula [3]

longitude $=\frac{\sum_{\mathrm{i}=1}^{\mathrm{n}}\left(x_{i} l_{i}\right)}{\sum_{\mathrm{i}=1}^{\mathrm{n}} l_{i}} \quad$ latitude $=\frac{\sum_{\mathrm{i}=1}^{\mathrm{n}}\left(y_{i} l_{i}\right)}{\sum_{\mathrm{i}=1}^{\mathrm{n}} l_{i}}$

where:

$x, y$ - coordinates of the studied $i^{\text {th }}$ points (cities)

li - weights expressed using the $\mathrm{i}^{\text {th }}$ unit (number of HQs or SCPI and CPI),

longitude, latitude - coordinates of the centroid.

Gravity centre of the Command and Control potential of cities

The centroid calculated based on the number of headquarters shifted east by about 14.5 degrees within the study period. At the beginning of this period, the centre of the headquarters of corporations was located near Gibraltar. By 2016, the centre had shifted to Tunisia. In the study period, a latitudinal shift also occurred by about 0.8 degrees to the south. The centres of gravity for individual sectors of the economy also clearly shifted eastward in the study period. Six out of ten sectors of the economy had their centres of gravity located in the western hemisphere in 2006, while in 2016, only three remained there. Healthcare was the westernmost sector in both 2006 and 2016. This sector also shifted the least to the east (by about 13.8 degrees). This sector was also the most northerly one (at about $40^{\circ} \mathrm{N}$ ). The centre of gravity of the IT sector was also located to the west of the centroids of the remaining sectors within the study period. However, a clear shift to the east, by about 11.5 degrees, occurred in this case, which confirms that the relocation of the headquarters of firms in this sector did occur during the study period. The centre of gravity of the headquarters of corporations in the energy sector also shifted substantially east, by about 13.8 degrees. Nevertheless, the centroid of the energy firms still remained in the western hemisphere $\left(12.8^{\circ} \mathrm{W}\right)$ in 2016 (Fig. 1).

The largest shift to the east was recorded in the case of the centre of gravity of the number of headquarters of consumer staples companies (shifted by 28.99 degrees), while the second largest shift was recorded by the utility sector (shifted by 27.86 degrees). The shifts of the centroids for consumer staples and for utilities were associated with the economic development of countries in Asia (such as China) and Eastern Europe which is growing rapidly (Egri, Tánczos 2018). Additionally, in time of economic crisis, conservative investors preferred to invest in utilities, considering it to be a more stable sector. The industrial sector was the one whose centroid remained the most eastern with respect to the overall centre of gravity of the number of corporate headquarters in the study period. Its shift to the east in the study period was relatively small (by about 3.9 degrees). Therefore, it may be inferred that it is companies from the industrial sector that are primarily located in the eastern hemisphere. In the study period, the largest shifts in the HQ centroids in the eastern hemisphere were recorded for the financials, telecommunications and materials sectors. It is noteworthy that the $\mathrm{HQ}$ centroid of the telecommunications sector moved to the north, and the magnitude of the northward shift was the greatest of all the sector-related centroids. Meanwhile, the financial and consumer staples sectors experienced the largest southward shift between 2006-2016, along with a small eastward shift. This results from the fact that new headquarters of companies were established in South America and the Middle East and that relatively longterm stability of location is typical for these sectors, which are considered to be strategic sectors for the national economies of many countries (Fig. 1)

In the case of the centre of gravity calculated for the value of the $\mathrm{CPI}$, it is possible to observe large differences in relation to the $\mathrm{HQ}$ distribution pattern. In order to identify the main regions of concentration of the command and control function, the financial 


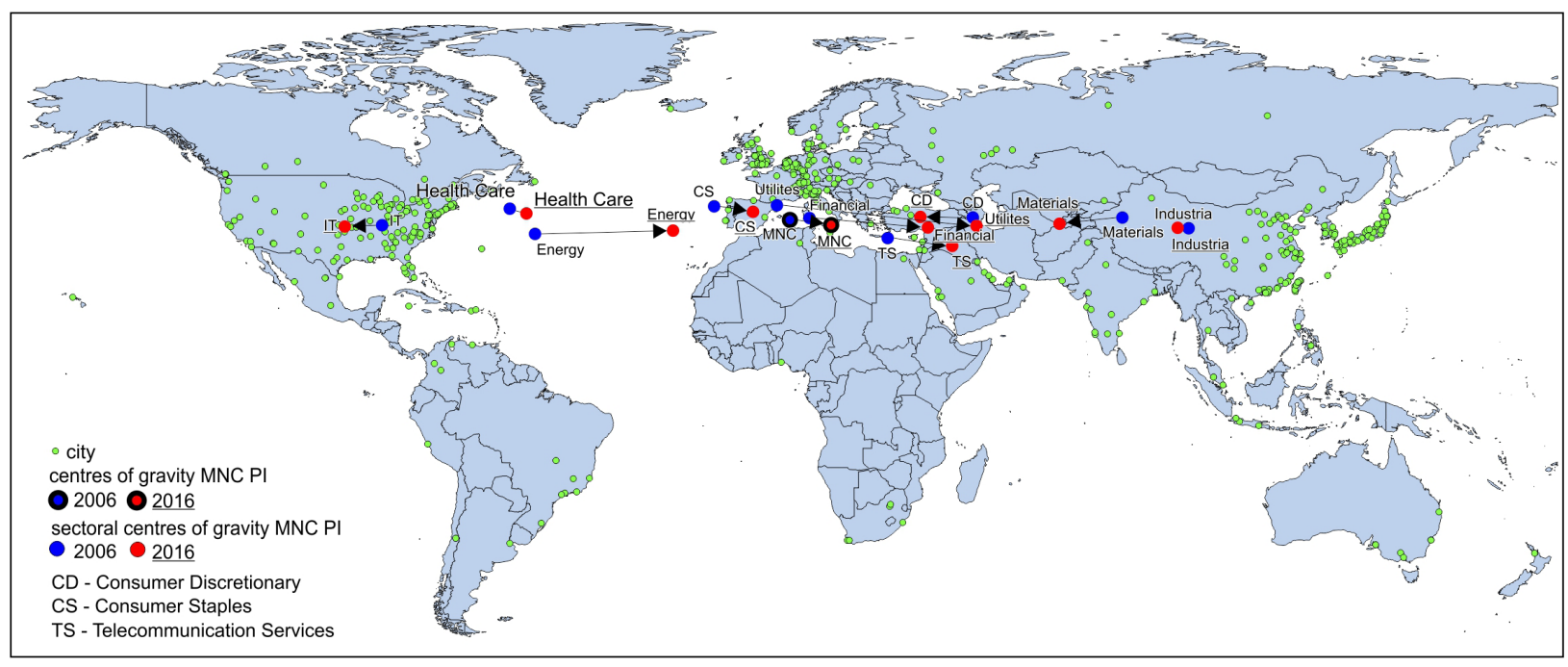

Figure 2. Centres of gravity according to the value of CPI and SCPI in 2006 and 2016. Source: Authors' own work based on Forbes Global 2000 (Forbes Global 2000, 2018)

potential of companies was calculated by accounting for the number of HQs. The centre of gravity of CPI in the years 20062016 shifted from the region between the Balearic Islands and Sardinia by 9.38 degrees to the east and 1.16 degrees to the south in the direction of eastern Sicily (Fig. 2). It has been shown that the location of (and shift in) the centroid is markedly different from the world's economic centre of gravity, as calculated by G. Tóth and Z. Nagy (2017), based on GDP values for selected countries. The world's economic centre of gravity is located in the western part of the Czech Republic and has shifted east in recent years but by an insignificant amount. This suggests that, despite general economic development in Asia in recent decades, the centre of gravity of the global economy has not shifted substantially eastward.

What can also be observed is a convergence between locations of the centre of gravity of the SCPI for individual sectors and corresponding HQ centroids (Fig. 2). The centre of gravity of the SCPI for IT was the most western one. Information technology is the foundation of the digital economy. The IT sector includes hardware equipment, software and internet services. IT commonly refers to the application of computer methods to solving practical problems in all aspects of life such as industry, commerce, medicine, and agriculture. IT represents, therefore, the use of computer and information science via hardware equipment, software, services and infrastructure, to create, store, and exchange information. The IT sector is also its employees who develop, implement, and use information technology (directly or indirectly). Technological innovations and their application take on different forms and often consequently involve specialised knowledge from various disciplines and branches of industry. The IT sector is closely tied to the life sciences as well as technologically advanced industries, the energy industry, and environmental protection.

Consequently, the shift of the centre of gravity representing the index of the C\&C potential of cities in the IT sector occurred in a western direction, despite the relocation (eastwards) of a large number of production facilities, for example, to developing countries. In the study period, the world C\&C centre for the IT sector, the city of San Jose in California, increased its share of potential, represented by the sCPI for the cities under analysis, from $38.6 \%$ in 2006 to $46.6 \%$ in 2016 , while the Tokyo's share fell from $17 \%$ to $3.4 \%$. Meanwhile, new and very important C\&C centres have emerged in the eastern hemisphere, in places such as Seoul (South Korea), Taipei City, Hsinchu City, Taoyuan City (Taiwan), Beijing and Shenzhen (China), and Bangalore (India). Additional concentration of IT potential occurred in the studied period of time in the western hemisphere, which led to a shift in the IT centre of gravity 8.5 degrees to the west, shifting from the East Coast of the United States to the interior of the country. The main region of concentration of IT headquarters remains Silicon Valley in California. The healthcare sector also remains rooted in the western hemisphere, with a shift to the east of 3.8 degrees in the studied period. Nevertheless, the shift of the centre of gravity for the C\&C potential for this sector confirms that slowly, yet progressively, the process of relocating companies from this sector into Asia, Eastern Europe and South America is also taking place.

The United States played a key role among countries with leading healthcare companies in the study period, with 20 ranked companies in 2006 or $45 \%$ of all companies in the ranked part of the sector. In 2016. the number of ranked healthcare companies in the United States increased to 24, although its overall share in the ranked part of the sector declined to $37 \%$. The second spot in the healthcare ranking was held by Japan, with 8 companies in 2006 and 10 companies in 2016. Subsequent spots were held by Switzerland, Ireland, Great Britain, and Germany. Two cities may be described as global centres of the healthcare industry - New York and Basel (Dorocki et al. 2017).

Based on the potential represented by the SCPI, the energy sector experienced the largest eastward shift in the centre of gravity. The shift of the centre of gravity of this sector in the study period was more than 31.4 degrees east, although it still remained in the western hemisphere. Although tied to its mineral resource base, the energy sector, is not closely tied spatially to that base in terms of its economic leadership. Corporations in the energy sector are concentrated primarily in North America (USA, Canada) and Western Europe (Holland, UK, France). The global centres of corporations doing business in the energy sector include Houston and Dallas in Texas, Calgary in Canada, and the Hague in the Netherlands. However, changes that occurred in the energy sector, in the sense of its privatisation and opening up to private investors in Asian and Eastern European countries 
(Dunkerley 1995), triggered the rise of energy sector powers such as China (Beijing) and Russia (Moscow) as well as Brazil and India.

However, the largest shift to the east in the study period was that of the public utility sector centroid. Its longitude in 2006 was 2.39 degrees east - and it had shifted to 45.4 degrees east by 2016 . This change was mainly due to the growth of China's economy, which helped China grow its share of world CPI in this sector from $1.8 \%$ to $32.4 \%$ during the study period. South Korea and Malaysia also made significant gains in this area. These changes altogether produced changes in city rank. In 2006 Paris held $26 \%$ of SCPI in the public utilities sector, while London, Madrid, and Tokyo held approximately 5\% each. In 2016 Beijing held $18 \%$ of the sector, followed by Hong Kong with $17 \%$. For comparison, the two cities stood at $0.4 \%$ and $1.4 \%$ in 2006 , respectively. Another city that made gains was Seoul with about $3 \%$. Paris declined more than $14 \%$ during the same period.

\section{Conclusions}

One may imagine a situation, where a decline in the financial performance of major corporations and the effect of this on the command and control functions of cities may result in improvement of the financial condition of remaining (smaller) firms in a given country. This may be beneficial for the stabilisation of the economy in times of recession, considering that executives of smaller firms make decisions independently and locally, and not somewhere in a city geographically remote from production facilities. This may favour local and regional economies as well as national economies. Therefore, declines in various financial indicators for corporations do not necessarily mean that there are major problems in the overall economy. Similarly, increases in corporate performance indicators may not necessarily imply success. In this context, the centres of gravity, including those for individual sectors calculated for entire economies, may be located in other geographic places. It is also possible that the shifts being observed for centres of gravity may be different than for the group of sectors studied here. Even though no single study can cover an entire economy, in subsequent studies it would be worthwhile to explore the significance of corporations with respect to entire economies, and to determine whether an increase in the significance of corporations and the command and control function of cities results from the growth of national economies - and may even exceed the national economic growth rate - or provides a contrast to national economic growth patterns.

\section{Summary}

In summary, there are three main rules to be recognised, which govern the distribution of, and changes in, the potential of cities based on the command and control functions of the headquarters of corporations hosted by these cities. First, three main regions may be identified which concentrate cities hosting the headquarters of corporations, based on the spatial distribution of the C\&C potential of cities in the study period. The three main regions are: Western Europe (the European Banana), United States, and Eastern Asia (primarily China and Japan). However, new areas were also identified, where the C\&C potential has begun to concentrate: the Middle East, South America (Brazil), and Eastern Europe.

Second, regardless of the analysis of the number of corporate headquarters, and of the potential calculated based on the Corporate Potential Index a shift of the centre of gravity of the $C \& C$ functions of cities in an easterly direction can be observed. This pertains to almost all sectors of the economy. However, the centroids of the knowledge-based sectors of the economy, such as IT and healthcare, are the westernmost ones.
The last major pattern is that the magnitude and direction of the shift of the centre of gravity of the number of headquarters in cities do not converge with the shift of the centroid based on the value of CPI. The best example of this fact is the IT sector, whose centre of gravity in the period 2006-2016, shifted eastward when calculated based on the number of $\mathrm{HQs}$, yet shifted westward when based on the total potential represented by the CPI. Therefore, the location and shift of the centre of gravity for a given sector largely depend upon the level of scientific advancement of the selected sector. This was confirmed by the research of $W$. Kilar (2015) who emphasised that the distribution of locations of corporate $\mathrm{HQs}$, the economic activity of which belong to the group of advanced technology industries, depends on the attributes of each geographic location, such as: the availability of large numbers of highly qualified employees, a substantial number of employees in the area of basic research (R\&D), the socioeconomic development of the area, where the HQs are located, developed telecommunications infrastructure, transportation accessibility, a "friendly" environment for the generation of new knowledge and technologies, major metropolitan areas, or geographic areas that concentrate companies from certain sectors engaged in specialised, advanced technologies. Areas satisfying such conditions are found primarily in the United States.

The largest shifts to the east in the study period were noted by sectors such as energy and financials. This is associated with the processes of globalisation and with the growing role of developing countries, primarily China. In 2016 , sectors such as industrials, materials, financials, and telecommunications found themselves in the economic realm of the eastern hemisphere. At the same time, the centroids of the IT, healthcare, consumer products and energy sectors remained in the western hemisphere.

Moreover, the shift occurred primarily longitudinally, while the latitudinal shifts were small and usually occurred in a southerly direction. This was mostly caused by an increase in the importance of major cities in Brazil, India, and in the general region of the Persian Gulf. Shifts in the centre of gravity are generally consistent with globalisation processes and the rank of world cities. In the $21^{\text {st }}$ century the intercity connectivities of key cities in south eastern Asia are growing much more rapidly than those of European cities and North American cities. On the other hand, marked increases in the connectivity of cities in Latin America do not strongly affect shifts in the centre of gravity of individual sectors and the overall centre of gravity.

\section{ORCID}

Piotr Raźniak (1) https://orcid.org/0000-0001-9757-7022

Sławomir Dorocki (iD https://orcid.org/0000-0001-6083-0346

Anna Winiarczyk-Raźniak (D) https://orcid.org/0000-0002-5276-5297 


\section{References}

Alderson, AS \& Beckfield, J 2004, 'Power and position in the world city system', American Journal of Sociology, vol. 109 no. 4, pp. 811-851.

Beaverstock, JV, Smith, RG \& Taylor, PJ 1999, 'A roster of world cities', Cities, vol. 16, no. 6, pp. 445-458.

Boyce, RR \& Clark, WAV 1964, 'The concept of shape in geography', Geographical Review, vol. 54, no. 4, pp. 561-572.

Cohen, RB 1981, 'The new international division of labor, multinational corporations and urban hierarchy' in Urbanization and Urban Planning in Capitalist Societies, eds M Dear \& A Scott, Methuen, London-New York, pp. 287-316.

Csomós, G 2013, 'The command and control centers of the United States (2006/2012): An analysis of industry sectors influencing the position of cities', Geoforum, vol. 12, no. 50, pp. 241-251.

Csomós, G \& Derudder, B 2014, 'European cities as command and control centres 2006-11', European Urban and Regional Studies, vol. 21, pp. 345-352.

Csomós, G \& Tóth, G 2016, 'Featured graphic. Modelling the shifting command and control function of cities through a gravity model based bidimensional regression analysis', Environment and Planning A, vol. 48, no. 4, pp.613-615.

Derudder, B \& Taylor, P 2016, 'Change in the World City Network, 2000-2012', The Professional Geographer, vol. 68, no. 4, pp. 624-637.

Dorocki, S \& Raźniak, P 2017, 'Globalne zmiany ekonomicznego centrum grawitacji w oparciu o funkcje kontrolno-zarządcze miast', [Global changes of economic centre of gravity based on control and management functions of cities], Studia Ekonomiczne, no. 320, pp. 140-156.

Dorocki, S, Raźniak, P \& Winiarczyk-Raźniak, A 2018, 'Zmiany funkcji kontrolno-zarządczych w miastach europejskich w dobie globalizacji' [Changes in the command and control functions in European Cities in the age of globalisation], Prace Komisji Geografii Przemysłu Polskiego Towarzystwa Geograficznego, vol. 32, no. 3, pp. 128-143.

Dorocki, S, Raźniak, P \& Winiarczyk-Raźniak, A 2019, 'Changes in the command and control potential of European cities in 2006-2016', Geographia Polonica, vol. 92, no. 3, pp. 275288.

Dorocki, S, Raźniak, P, Winiarczyk-Raźniak, A \& Boguś, M 2017, 'The role of global cities in creation of innovative industry sectors. Case study - life sciences sector' in Proceedings of the 5th International Conference IMES, eds O Dvouletý, M Lukeš \& J Mísar, University of Economics, Prague, pp. $136-146$.

Dunkerley, J 1995, 'Financing the energy sector in developing countries', Energy Policy, vol. 23, no. 11, pp. 929-939.

Egri, Z \& Tánczos, T 2018, 'The spatial peculiarities of economic and social convergence in Central and Eastern Europe', Regional Statistics, vol. 8, no. 1, pp. 49-77.

Forbes Global 2000 2018. Available from: <www.forbes.com>. [17 October 2018].

Friedmann, J 1986, 'The world city hypothesis', Development and Change, vol. 17, 69-83.

Friedmann, J \& Wolff, G 1982, 'World city formation: an agenda for research and action (urbanization process)', International Journal of Urban \& Regional Research, vol. 6, no. 3, pp. 309-344.

Garbacz, Ch \& Thompson, HG Jr 2007, 'Demand for telecommunication services in developing countries', Telecommunications Policy, vol. 31, no. 5, pp. 276-289.

Godfrey, BJ \& Zhou, Y 1999, 'Ranking world cities: Multinational corporations and the global urban hierarchy', Urban Geography, vol. 20, no. 3, pp. 268-281.
Goerzen, A, Asmussen, CG \& Nielsen, BB 2013. 'Global cities and multinational enterprise location strategy', Journal of International Business Studies, vol 44, no. 5, pp. 427-450.

Grether, JM \& Mathys, NA 2010, 'Is the world's economic centre of gravity already in Asia?', Area, vol. 42, pp. 47-50.

Hall, P 1966, The World Cities. Heinemann, London.

Hennemann, S \& Derudder, B 2014, 'An alternative approach to the calculation and analysis of connectivity in the world city network', Environment and Planning B, vol. 41, no. 3, pp. 392-412.

Huanfeng, D \& Peiyi, L 2009, 'The variation contrastive analysis of economy gravity center and regional pollution gravity center of China in 1986-2006', Economic Geogrophy, 29(10), pp. 1629-1633.

I-Hui, Ch \& Wall HJ 2005, 'Controlling for heterogeneity in gravity models of trade and integration', Federal Reserve Bank of St. Louis Review, vol. 87(1), pp. 49-63.

Jażdżewska, I 2006, 'Zmiany położenia środka ciężkości miast i ludności miejskiej w Polsce w XX wieku' [Changes in the center of gravity of cities and urban populations in Poland in the 20th century], Przegląd Geograficzny, vol. 78, no. 4, pp. 561-574.

Kilar, W 2015, 'Settlement concentration of economic potential represented by IT corporations', Geographia Polonica, vol. 88 , no. 1 , pp. 123-141.

Kincses, Á, Nagy, Z \& Tóth, G 2013, 'Prostorske strukture v Evropi', Acta Geographica Slovenica, vol. 53, no. 1, pp. 1-36.

Klein, LR 2009, 'Measurement of a shift in the world's center of economic gravity', Journal of Policy Modeling, vo. 31, no. 4, pp. 489-492.

Kot, J 2007, 'Kriging - A method of statistical interpolation of spatial data', Acta Universitatis Lodziensis. Folia Oeconomica, vol. 206, pp. 89-99.

Kostrubiec, B 1972, 'Analiza zjawisk koncentracji w sieci osadniczej' [Analysis of concentration phenomena in settlement network], Prace Geograficzne, vol. 93.

Liu, X, Derudder, B, Witlox, F \& Hoyler, M 2014, 'Cities as networks within networks of cities: The evolution of the city/ firm-duality in the world city network, 2000-2010', Tijdschrift voor economische en sociale geographie, vol. 105, no. 4, pp. $465-482$.

Liu, X, Derruder, B \& Taylor, P 2014, 'Mapping the evolution of hierarchical and regional tendencies in the world city network, 2000-2010', Computers, Environment and Urban Systems, vol. 43, pp. 51-66.

Masik, G 2016, 'Economic resilience: The case of Poland and certain European regions', Geographia Polonica, vol. 89, no. 4, pp. 457-471.

Masik, G 2019, 'Economic sectors in the research of economic resilience of regions', Studies of the Industrial Geography Commission of the Polish Geographical Society, vol. 33, no. 1, pp. 117-129.

Neal, Z 2016, 'Well connected compared to what? Rethinking frames of reference in world city network research', Environment \& Planning A, vol. 49, no. 12, pp. 2859-2877.

Neal, Z, Derudder, B \& Taylor, PJ 2019, 'Should I stay or should I go: Predicting advanced producer services firm expansion and contraction', International Regional Science Review, vol. 42, no. 2, pp. 207-229.

Quah, D 2011, 'The global economy's shifting centre of gravity, Global Policy', vol. 2(1), pp. 3-9.

Raźniak, P, Dorocki, S \& Winiarczyk-Raźniak, A 2017, 'Permanence of economic potential of cities based on sector development', Chinese Geographical Sciences, vol. 1, no. 27, pp. 123-136. 
Raźniak, P, Dorocki, S \& Winiarczyk-Raźniak, A 2018, 'Eastern European cities as command and control centres in time of economic crisis', Acta Geographica Slovenica, vol. 58, no. 2, pp. 101-110.

Raźniak, P, Dorocki, S \& Winiarczyk-Raźniak, A2019, 'Resistance of cities performing command and control functions in Central and Eastern Europe to the economic crisis', Prace Komisji Geografii Przemysłu Polskiego Towarzystwa Geograficznego, vol. 33, no. 2, pp. 45-58.

Ramos, R \& Suriñach, J 2017, 'A gravity model of migration between the ENC and the EU', Tijdschrift voor Economische en Sociale Geografie, vol. 1, pp. 21-35.

Sassen, S 1988, The mobility of labor and capital. A study in international investment and capital flow, Cambridge University Press, Cambridge.

Sassen, S 1991, The Global City: New York, London, Tokyo, Princeton University Press, Princeton.

Sassen, S 2000, 'The global city: Strategic site/new frontier', American Studies, vol. 41, no. 2/3, pp. 79-95.

Scharlig, A 1973, 'About the confusion between the center of gravity and Weber's optimum', Regional and Urban Economics, vol. 3, no. 4, pp. 371-382.

Stein, ML 1999, Interpolation of spatial data. Some theory for Kriging, Springer Series in Statistics, Springer, New York.

Śleszyński, P 2018, 'Research topics of geography of enterprise and decision-control functions in Poland against global trends', Prace Komisji Geografii Przemysłu Polskiego Towarzystwa Geograficznego Geograficznego, vol. 32, no. 4, pp. 23-47.

Taylor, PJ, Derudder, B, Faulconbridge, J, Hoyler, M \& Ni, P 2014, 'Advanced producer service firms as strategic networks, global cities as strategic places', Economic Geography, vol. 90, no. 3, pp. 67-291.

Taylor, PJ \& Csomós, G 2012, 'Cities as control and command centres: Analysis and interpretation', Cities, vol. 29, no. 6, pp. 408-411.

Tóth, G \& Csomós, G 2016, 'Mapping the position of cities in corporate research and development through a gravity model-based bidimensional regression analysis', Regional Statistics, vol. 6, no. 1, pp. 217-220.

Tóth, G \& Nagy, Z 2017, 'The world's economic centre of gravity', Regional Statistics, vol. 6, no. 2, pp. 177-180.

Yang, X, Derudder, B, Taylor, P, Ni, P \& Shen, W 2017, 'Asymmetric global network connectivities in the world city network 2013', Cities, vol. 60, pp. 84-90.

Wojciechowski, L 2004, 'Ekonomiczne modele grawitacyjne przykłady ich zastosowania w literaturze światowej i polskiej' [Economic gravity models - Examples of application in the related literature in the world and in Poland], Zeszyty Naukowe Akademii Ekonomicznej w Poznaniu, vol. 47, pp. 9-37. 